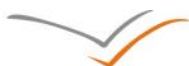

\title{
VERSITA
}

\section{Expert System Approach to the Assessment of Spiritual Intelligence Impact for Decision-making Performance}

\author{
Savo Stupar, Amila Pilav-Velić, Elvir Šahić \\ University of Sarajevo, School of Economics and Business, Bosnia and Herzegovina
}

\begin{abstract}
Background: In contrast to the rational (IQ) and emotional intelligence (EQ), spiritual intelligence (SQ) is often underestimated and insufficiently investigated. This type of intelligence refers to our approach to the issue of the meaning and value of life, in terms that our actions are placed in a wider context. Objectives: The aim of this paper is to investigate in which extent spiritual intelligence determines the decision making process. In this context, the success of business decision is assigned as its functionality as one of the most prominent feature of successful decision. Methods: The inductive method of building an expert system, i.e. a knowledge based system (Doctus Knowledge-Based Expert System Shell) and casebased concluding on the degree of informativeness (with a key impact on functionality of decision) of individual components (Case Based Reasoning) are used in testing this relationship. Results: The study demonstrates the fact that most of respondents (managers) have not been even familiar with attributes of $\mathrm{SI}$ as well as their relationship with decision making process. Conclusions: Identification of the most significant components of SI that affect effectiveness of decisions would allow managers to focus on those which mostly contribute to the functionality of their decisions.
\end{abstract}

Key words: spiritual intelligence, spiritual capital, expert systems, managerial decision making, Doctus

JEL main category: Business Administration and Business Economics \& Marketing

JEL classification: M10, M15

Paper type: Research article

Received: 24, July, 2013

Revised: 5, September, 2013

Accepted: 14, October, 2013

Citation: Stupar, S., Pilav-Velić, A., Šahić, E. (2013). "Expert System Approach to the Assessment of Spiritual Intelligence Impact for Decision-making Performance", Business Systems Research, Vol. 4, No. 2, pp. 68-78.

DOI: 10.2478/bsri-2013-0013

\section{Introduction}

In contrast to the rational (IQ) and emotional intelligence (EQ), spiritual intelligence (SQ) is often underestimated and insufficiently investigated, particularly because there is now biological evidence to support its existence (e.g. Newburg, et al., 2002; Joseph et al., 2003). This type of intelligence refers to our approach to the issue of the meaning and value of life, in terms that our actions are placed in a wider context (Lerner, 2000). He perceives SQ as "a deep inner knowing that our lives have meaning through our innermost being as manifestations of the ultimate goodness of the universe" (pp. 5). It allows us to deal with the existing limitations and provides us the ability to discern. 
Ideally, three basic types of intelligence (rational - IQ, emotional - EQ and spiritual - SQ) work together and complement each other (e.g. Gardner, 2000). The idea that spiritual intelligence represents an upgrade and the connective tissue between other two intelligences (IQ and $E Q)$ was the inspiration and impetus to study relationship between effectiveness of managerial decisions and components of spiritual intelligence (such as those proposed by George, 2006; White, 2006). Goal of the paper is to assess relationship between each component of spiritual intelligence and success of business decisions. The research methodology includes an expert system (ES), created by inductive method using the Doctus Knowledge Based System Shell and reasoning based on cases - Case Based Reasoning technique. The knowledge base is made aiming to detect new knowledge (based on cases /decisions from practice) relevant for the decision makers and decision making process.

Hence, the paper is organized as follows. First, the existing literature background is discussed in order for average reader get the comprehensive image of the addressed issue. Then, the data collection and sampling process including research methodology are explained. Within fifth section, research results are presented wherein the main issues and directions for future research are indicated. Finally, the concluding remarks are outlined.

\section{Literature review}

Today, in ever changing world, people strive to find meaning in their lives (Fairholm, 1996). "The materialism and individualism of Western culture" (Sisk, 2002) induced a hunger for spirituality. Since the organization and workplace have become the central points of our lives and springhead of values in society, spirituality is in focus of numerous research studies. People tend to be connected with their workplaces and value their jobs more than paychecks (Klenke, 2003). Thus, Rosner (2001) indicated the work should serve to spirituality, not spirituality to work. Spirituality integrates our personal values and needs with professional environment in the more meaningful context and entirety reflecting ourselves. Tombaugh, Mayfield and Durand (2011) labelled this dynamic aspect of spirituality as "spiritual expression at work" (SEW) refering "to the impact or influence of personal spirituality on workplace thoughts, behaviours and interactions" (pp. 147). In addition, personal spirituality of the worker is leading to "the motivational organizational culture" resulting in improved overall performance and organizational excellence (Marques, 2005, pp. 283). Many researches show a positive relation between personal spirituality and positive effect on organizational commitment and culture (e.g. Tombaugh et al., 2011; Greenfield et al., 2009; Cole et al., 2008; Clark et al., 2007; Perrone et al., 2006.).

Namely, Zohar et al., (2000) noticed that "computers have IQ, some animals can have high $E Q$, but only human have $S Q$ as ability to question why we are here". Spiritual intelligence is "more than individual mental ability" and it "connects the personal to the transpersonal and the self to spirit" (Vaughan, 2002, pp. 19). In contrast to rational intelligence which is about "thinking and solving logical problems" and emotional intelligence which "deals with feeling and allows us to judge the situation", spiritual intelligence "allows us to ask whether we want to be in present situation", enabling connection ",between mind and body as well as between reason and emotion" (Kadkhoda et al., 2012, pp. 172).

Probably one of the most comprehensive definitions of spiritual intelligence is proposed by White (2006), based on extensive literature review process, which SQ designated as "a set of seven cognitive characteristics:

- $S Q$ is a rational higher level of consciousness;

- $S Q$ is the capacity for affective intellectual development;

- SQ implies that an individual has the unique ability to construct a vision that is infused with a notion of ultimate purpose;

- $S Q$ is the ability of intuitively seeing connections between existential ideas and varied lifeworld experiences;

- SQ provides a grounding for authentic self-efficacy coupled with an empathetic understanding of others; 
- $S Q$ is a predisposition to see inherent connections that may not be tangible and to seek existential answers that support a rational theoretical orientation, and

- Scientific research suggests that the brain's actual "physiological organization" is designed to produce spiritual thoughts".

Precisely, these multiple dimensions make SQ inevitable factor in decision-making process. Particularly, because it involves a capacity for a deep understanding of questions but also set of skills and resources that facilitate problem solving and goal attainment (Sisk, 2002; Wolman, 2001). The big picture and relation between our actions and greater context are enabled by SQ (Frankl, 1985). Spiritual intelligence deals with problems of meaning and value (Kadkhoda and Jahani, 2012) offering solutions directed toward the benefit of all (Sisk, 2002). On the other side, respecting continual changes in organizations as well as in their environments, „it seems that a new and deeper intelligence is needed to help a manager to manage better and a leader to lead more effectively" (George, 2006, pp.4).

Wolf (2004) proclaimed spirituality at workplace as a leadership responsibility, using term "spiritual leadership". Specifically, spiritual leadership implies rejection of past models of human leadership focused on power, wealth and prestige (Fairholm, 1996). The modern spiritual leaders are moral leaders. They train and educate followers, motivate and help them to feel powerful and able to accomplish their tasks. In this context, organizational community has key role in the new leadership model determining organization as economic enterprise but also human system.

Moreover, Zohar (2005) defined spiritually intelligent leadership with following characteristics: "Self-Awareness (knowing what I believe in and value), Spontaneity (living in and being responsive to the moment), Being Vision- and Value-Led (acting from principles and deep beliefs), living accordingly Holism (seeing larger patterns, relationships, and connections) and a Sense of Vocation (feeling called upon to serve a higher purpose)" (Luckock, 2008, pp. 375).

Hence, respecting the complexity of the decision-making process and indispensable role of human beings in this process, spiritual intelligence definitely has significant influence on the quality of decision-making (George, 2006). In addition to the experience and skills, every manager has own personality that determines personal style in decision-making process, but also the final choice. Due the need for a manager/leader to maintain the view of "the big picture", spiritual intelligence achieves its true significance given that term "spiritual" means to be in touch with a broader, deeper and richer context and reflectively assess which course of action is more meaningful than another (White, 2006).

\section{Methodology}

\section{Survey instrument}

The research was conducted using specially designed questionnaire for each particular decision. The questionnaire is actually card entitled as Attributes (with 32 items) within an expert system developed using Doctus's shell. All items were clearly and undoubtedly defined in order to get valid and comparable responses. Moreover, appropriate definitions were provided. Respondents were asked to evaluate importance of each component of spiritual intelligence (which an attribute is the most informative) for successful business decision making.

The first attribute represents dependent variable defined as underlying attribute while other 31 attributes are independent variables which indicate decision criteria that affect the outcome of the decision. Thus, if certain decision contributes in problem solving we can say that it was successful decision. If the problem wasn't solved or it was necessary to conduct additional analysis for decision making process we can state that this decision is not successful. But through the next 31 questions as different decision criteria, the reason for the decision failure can be revealed. 


\section{Table 1}

\section{Research Instrument}

\begin{tabular}{|c|c|c|c|c|}
\hline Decision criteria related to $S Q$ & Outcome 1 & Outcome 2 & Outcome 3 & Outcome 4 \\
\hline Functionality of the decision & $\begin{array}{l}\text { Problem is not } \\
\text { solved }\end{array}$ & Partially solved & $\begin{array}{l}\text { Meets } \\
\text { expectations }\end{array}$ & $\begin{array}{l}\text { Exceeds } \\
\text { expectations }\end{array}$ \\
\hline $\begin{array}{l}\text { Self-knowledge (knowing of } \\
\text { self) }\end{array}$ & Not at all & In less extent & Enough & Very well \\
\hline Having time for silence & Not at all & Sometimes & A lot of time & \\
\hline Meditation & Not at all & Sometimes & Often & \\
\hline Spending time in nature & Not at all & Sometimes & Often & A lot of time \\
\hline Judging people & Constantly & Often & Rarely & Never \\
\hline Power of donating & $\begin{array}{l}\text { Doesn' } \dagger \\
\text { appreciate }\end{array}$ & $\begin{array}{l}\text { Appreciates but } \\
\text { doesn't give } \\
\text { donations }\end{array}$ & $\begin{array}{l}\text { Appreciates and } \\
\text { gives donations }\end{array}$ & $\begin{array}{l}\text { Extremely } \\
\text { appreciates and } \\
\text { gives donations }\end{array}$ \\
\hline Giving donations & Never & Rarely & Often & In all occasions \\
\hline Receiving donations & Never & Rarely & Often & In all occasions \\
\hline $\begin{array}{l}\text { Provision of giving and } \\
\text { receiving }\end{array}$ & No & Yes & & \\
\hline Influence on karma/destiny & $\begin{array}{l}\text { Doesn't make } \\
\text { influence }\end{array}$ & $\begin{array}{l}\text { Trying to make an } \\
\text { influence }\end{array}$ & $\begin{array}{l}\text { Influences } \\
\text { significantly }\end{array}$ & \\
\hline $\begin{array}{l}\text { Awareness of any decision in } \\
\text { the present }\end{array}$ & Unawareness & Partial awareness & $\begin{array}{l}\text { Complete } \\
\text { awareness }\end{array}$ & \\
\hline $\begin{array}{l}\text { Thinking about consequences } \\
\text { of choice }\end{array}$ & Not at all & Sometimes & Often & Always \\
\hline $\begin{array}{l}\text { Listening to own heart when } \\
\text { deciding }\end{array}$ & Never & Rarely & Often & Always \\
\hline $\begin{array}{l}\text { Success with minimal effort } \\
\text { (",miracle") }\end{array}$ & $\begin{array}{l}\text { Success with a lot } \\
\text { of effort }\end{array}$ & $\begin{array}{l}\text { Success with } \\
\text { minimal effort }\end{array}$ & & \\
\hline Accepting the situation & No & Yes & & \\
\hline $\begin{array}{l}\text { Accepting responsibility for the } \\
\text { situation }\end{array}$ & No & Partially & Yes & \\
\hline Defending own positions & Always & Sometimes & Never & \\
\hline Significance of intention & $\begin{array}{l}\text { Doesn't realize the } \\
\text { significance of } \\
\text { intention }\end{array}$ & $\begin{array}{l}\text { Realize the } \\
\text { significance of } \\
\text { intention }\end{array}$ & $\begin{array}{l}\text { Realize the } \\
\text { significance of } \\
\text { intention very well }\end{array}$ & \\
\hline Entry into silence & Never & Sometimes & Often & \\
\hline Release of own intensions & Never & Sometimes & Often & \\
\hline $\begin{array}{l}\text { Remain in the state of } \\
\text { introspection }\end{array}$ & $\begin{array}{l}\text { Take care about } \\
\text { others' opinions }\end{array}$ & $\begin{array}{l}\text { View yourself } \\
\text { through others' } \\
\text { eyes, }\end{array}$ & $\begin{array}{l}\text { Self-reference } \\
\text { point }\end{array}$ & \\
\hline $\begin{array}{l}\text { Relation to the outcome of } \\
\text { decision }\end{array}$ & $\begin{array}{l}\text { Related to the } \\
\text { outcome }\end{array}$ & $\begin{array}{l}\text { Related to the } \\
\text { outcome in less } \\
\text { extent }\end{array}$ & $\begin{array}{l}\text { Accept "the } \\
\text { wisdom of } \\
\text { uncertainty" }\end{array}$ & \\
\hline $\begin{array}{l}\text { Thinking about details of the } \\
\text { performance }\end{array}$ & $\begin{array}{l}\text { Makes detailed } \\
\text { performance plan }\end{array}$ & $\begin{array}{l}\text { Makes rough } \\
\text { performance } \\
\text { plan }\end{array}$ & $\begin{array}{l}\text { "Leaves" } \\
\text { performance } \\
\text { plan to cosmos }\end{array}$ & \\
\hline $\begin{array}{l}\text { Relation to the outcome of } \\
\text { intention }\end{array}$ & $\begin{array}{l}\text { Related to the } \\
\text { outcome }\end{array}$ & $\begin{array}{l}\text { Related to the } \\
\text { outcome in less } \\
\text { extent }\end{array}$ & $\begin{array}{l}\text { Accept "the } \\
\text { wisdom of } \\
\text { uncertainty" }\end{array}$ & $\begin{array}{l}\text { No relation to the } \\
\text { outcome }\end{array}$ \\
\hline Choice of solutions & $\begin{array}{l}\text { Imposing of own } \\
\text { ideas }\end{array}$ & $\begin{array}{l}\text { Making decision } \\
\text { on force }\end{array}$ & $\begin{array}{l}\text { Active attitude } \\
\text { towards the } \\
\text { solution }\end{array}$ & \\
\hline $\begin{array}{l}\text { Accepting uncertainty } \\
\text { Openness to a variety of } \\
\text { options }\end{array}$ & $\begin{array}{l}\text { Never } \\
\text { Prefers only one } \\
\text { option of decision }\end{array}$ & $\begin{array}{l}\text { Sometimes } \\
\text { Prefers 2-3 options }\end{array}$ & $\begin{array}{l}\text { Always } \\
\text { Unlimited number } \\
\text { of options }\end{array}$ & \\
\hline $\begin{array}{l}\text { Awareness of life goal } \\
\text { (Dharma) }\end{array}$ & No & Not enough & $\begin{array}{l}\text { Yes, quite aware } \\
\text { of life goal }\end{array}$ & \\
\hline $\begin{array}{l}\text { Revealing of true self (special } \\
\text { gifts) }\end{array}$ & $\begin{array}{l}\text { Doesn't know } \\
\text { about own } \\
\text { special gifts }\end{array}$ & $\begin{array}{l}\text { Knows for own } \\
\text { special gifts, but } \\
\text { doesn't know how } \\
\text { to use them }\end{array}$ & $\begin{array}{l}\text { Knows for special } \\
\text { gifts and use them }\end{array}$ & \\
\hline Expression of special gift & Doesn't express & $\begin{array}{l}\text { Expresses } \\
\text { occasionally }\end{array}$ & Always expresses & \\
\hline Service to humanity & Yes & No & & \\
\hline
\end{tabular}

Source: Authors' work 
As we already indicated, this is not the final number of decision criteria, but due to the complexity of the successful decision making process, it was necessary to reduce the number of elements that determine the success of the decision. In this context the success of (quality) the decision includes its functionality as the most prominent feature of the quality decision. Specifically, the decision should contribute to the organizational effectiveness (efficiency), otherwise it is not a good decision. In the short term, the company will be effective, if its shortterm activities are functional. Also, a decision will be functional if it meets the immediate needs for which it was made. Considering the fact that every decision is made to be functional and to produce certain outcomes, we can take the functionality as one of the essential elements for quality decisions. In line with this, the respondents selected one of four given options within the questionnaire and hence defined successful decision in accordance with their experiences and beliefs.

\section{Sampling and data collection}

The data for this study were collected using a survey research method. The sample is comprised of managers in the banking industry, architecture, mechanical engineering, IT managers, financial managers, etc. Managers answered the questions related to their perceptions of the spiritual intelligence's components for the success or failure of a particular business decision. Final sample consists of 34 managers (out of initially contacted 90 managers) including 61 cases as different decisions which they made. Out of 61 questionnaires, two managers responded to 5 different questionnaires for 5 different decisions (10 questionnaires), two managers responded to 4 questionnaires for 4 different decisions (8), five managers responded to 3 questionnaires for 3 different decisions (15), three managers responded to 2 questionnaires for 2 different decisions (6) and finally 22 managers responded to only one questionnaire. The data were conducted using the Computer-assisted telephone interviewing (CATI).

\section{Developing expert system}

The research methodology includes an expert system (ES), created by inductive method using the Doctus Knowledge Based System Shell and reasoning based on cases - Case Based Reasoning technique. The knowledge base is made with intention to detect new knowledge (based on cases / decisions from practice) relevant for the decision making process. This new knowledge should be based on use of "soft methods" in assessment of significance of the individual spiritual intelligence components in order to improve decision-making process. For the research purposes, a prototype expert system will analyze 61 implemented managerial decisions in relation to the 31 decision-making criteria, or components of spiritual intelligence, and to "suggest" the most informative criteria in relation to the functionality of decisions.

For each decision, manager is required to answer what was its function, or whether that decision contributed to the particular solution, or the problem was solved only partially by implementation of these decisions, or whether it fully met expectations or its realization was obtained more than expected. The determination of attribute was the first step in building an expert system. Within Attributes card all attributes, their values and outcomes needed for the estimation process of decision functionality are listed. Thus, we entered the name and attributes values which contain decision on assessment of decision functionality. The name of that attribute is functionality of the decision (FD). When entering data, attention should be paid to the order of these values. Since we first entered less desirable values, the first value is problem is not solved, followed by all other values to the value more than expectations. To define an attribute as outcome attribute we used the command Edit/Set to Decision Attribute. Afterward the remaining attributes with associated values were entered.

The next stage in developing ES was cases entry and creating a graph of activities. Cases represent already made decisions, for which we know whether they were functional (meet or exceed expectations) or not (the problem is not solved or partially solved). Cases entry was done by entering the name of the case, its values of the underlying attributes (decision attribute) for each the registered case (dependent variable) and decision. After completion, the result was table of cases with their outcomes. Based on the entered cases rules of inference were derived. Method of polar branching divided each node of the graph into two 
branches, while effective branching method divided each node into two or more branches (if applicable) (Doctus Knowledge Based System). The order of attributes depended on the coefficient of informativeness for each attribute. Coefficient of informativeness indicated to which extent attribute is a crucial for decision-making, and mathematically it is equal to entropy of attributes calculated on the basis of frequency for each value in cases entered.

Rules are generated after the results were obtained by Case Based Reasoning process. When data about new decisions were collected and entered into the card Cases, it was also necessary to enter the attribute values of new decisions and hence running command Reason (deductive reasoning) enabled assessment of the functionality for each entered decision.

\section{Research results}

After 61 questionnaires were entered into the base of cases within an expert system (Card Cases), in order to get the most informative attributes for functional decision, we launched Command Knowledge Management -> Inductive Reasoning (Case Based Reasoning). Then in the dialog window Case Based Graph Setup within the card of Benchmark Method heuristic method of a decision tree generation is selected, and in the Learning Cases tab within the same dialog box, the option All cases is chosen. After that, the research results in the form of the most informative attributes' tree (Figure 1) are obtained on the card Case Based Graph.

Figure 1

Case Based Graph

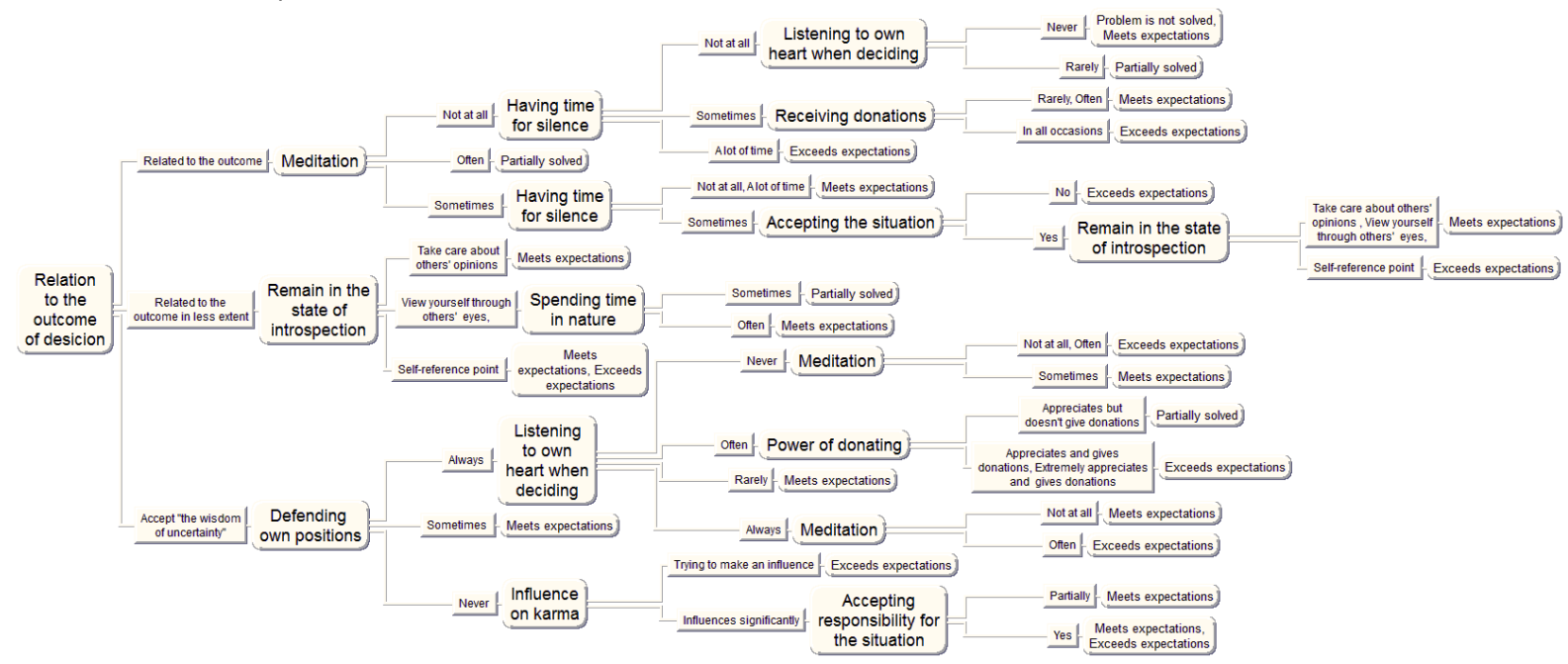

Source: Authors' work

This study demonstrates that the most informative attribute for decision's success (functionality) is the Relation to the outcome of the decision. When the value of this attribute is Mostly related to the outcome of the decision, the next level of informativeness (significance) has the attribute Meditation, which is (in the hierarchy of attributes from deductive hierarchical graph) an integral part of Self-knowledge attribute. If the value of Meditation attribute is doesn't meditate and sometimes meditates, then the next crucial attribute is Taking time for silence. But if the value of Meditation attribute is often meditates, the value of the independent variable functionality of the decision (FD) is partially solved problem. When Relation to the outcome of the decision has value less related to the outcome of the decision, the next crucial attribute is Remain in the state of introspection, and when the value of this attribute is influenced by the opinion and criticism of others, Functionality of decision (FD) has a value meets expectations, while the value of this attribute is view yourself through others' eyes, and self- reference point, there are new critical attributes. At the first, there is Spending time in nature attribute, and the second Self-knowledge attribute. If the value of the first attribute is spending time periodically, then the functionality of decision (FD) is partially solved 
problem, and when the value is spending time often, then FD meets expectations. Also the value of the second attribute (self-knowledge) is know enough, then FD exceed expectations, but when the value is extremely familiar, then FD meets expectations. And finally, if the value of the Relation to the outcome of the decision attribute is Accepting the uncertainty, then the next most informative attribute is Defending your attitudes, etc.

In this partial view, it is obvious how to read the different values of the FD variable from a graph. Inconsistency of particular results with previously introduced spiritual principles could be explained by the three facts: the first one is that some components of spiritual intelligence are differently perceived in the Western and Eastern culture, the second possible reason is that we defined desirability of attribute values in accordance with the tradition of the Eastern culture, and the third fact is that the participants follow the tradition of the Western culture.

In fact, a large number of interviewed managers considered that the Relation to the outcome of the decision, is almost a necessary condition for the successful decision. In Eastern culture, there is a totally different principle which says that if we want to get anything in the physical world, we must reject our ties to the object, but this does not mean that we should renounce our intention to achieve the goal. Detachment is based on unconditional faith in our true selves. Precisely, this result is evidence how culture and spiritual intelligence of managers as two intangible values affect the decision-making process which demonstrates the complexity of this issue. Moreover, in the Table 2, there is a list of the informativeness of the spiritual intelligence components (independent variables), sorted by the degree of their importance in relation to the functionality of the decision (dependent variable).

Table 2

Components of spiritual intelligence sorted by coefficient of informativeness

\begin{tabular}{|c|c|c|}
\hline Attribute & Informativity & Density \\
\hline Relation to the outcome of decision & 0.0599 & 4.92 \\
\hline Judging people & 0.0598 & 4.92 \\
\hline Receiving donations & 0.0591 & 4.85 \\
\hline Power of donating & 0.0561 & 4.61 \\
\hline Having time for silence & 0.0535 & 4.39 \\
\hline Listening to own heart when deciding & 0.0476 & 3.91 \\
\hline Remain in the state of introspection & 0.0451 & 3.70 \\
\hline Thinking about details of the performance & 0.0400 & 3.28 \\
\hline Defending own positions & 0.0392 & 3.22 \\
\hline Revealing of true self (special gifts) & 0.0383 & 3.14 \\
\hline Giving donations & 0.0379 & 3.11 \\
\hline Self-knowledge & 0.0372 & 3.06 \\
\hline Accepting responsibility for the situation & 0.0361 & 2.97 \\
\hline Thinking about consequences of choice & 0.0343 & 2.81 \\
\hline Meditation & 0.0305 & 2.50 \\
\hline Entry into silence & 0.0304 & 2.50 \\
\hline Spending time in nature & 0.0285 & 2.34 \\
\hline Relation to the outcome of intention & 0.0279 & 2.29 \\
\hline Significance of intention & 0.0259 & 2.13 \\
\hline Awareness of any decision in the present & 0.0226 & 1.86 \\
\hline Service to humanity & 0.0226 & 1.85 \\
\hline Openness to a variety of options & 0.0216 & 1.77 \\
\hline Accepting uncertainty & 0.0203 & 1.67 \\
\hline Expression of special gift & 0.0182 & 1.50 \\
\hline Awareness of life goal & 0.0170 & 1.40 \\
\hline Release of own intensions & 0.0133 & 1.09 \\
\hline Success with minimal effort & 0.0130 & 1.07 \\
\hline Accepting the situation & 0.0116 & 0.95 \\
\hline Provision of giving and receiving & 0.0056 & 0.46 \\
\hline
\end{tabular}

Source: Authors' work

Using command Knowledge Management -> Extract Rules, it is possible to extract the most informative attributes (those that appear in the Case Based Graph) in the newly created ES with a extracted number of attributes (Table 3 and Figure 2). 
Table 3

The most significant components of spiritual intelligence (13) within newly created expert system

\begin{tabular}{|c|c|c|c|c|}
\hline Decision criteria related to $S Q$ & Outcome 1 & Outcome 2 & Outcome 3 & Outcome 4 \\
\hline Functionality of the decision & $\begin{array}{l}\text { Problem is not } \\
\text { solved }\end{array}$ & Partially solved & $\begin{array}{l}\text { Meets } \\
\text { expectations }\end{array}$ & $\begin{array}{l}\text { Exceeds } \\
\text { expectations }\end{array}$ \\
\hline $\begin{array}{l}\text { Relation to the outcome of } \\
\text { decision }\end{array}$ & $\begin{array}{l}\text { Related to the } \\
\text { outcome }\end{array}$ & $\begin{array}{l}\text { Related to the } \\
\text { outcome in } \\
\text { less extent }\end{array}$ & $\begin{array}{l}\text { Accept „the } \\
\text { wisdom of } \\
\text { uncertainty" }\end{array}$ & \\
\hline Meditation & Not at all & Sometimes & Often & \\
\hline Having time for silence & Not at all & Sometimes & A lot of time & \\
\hline $\begin{array}{l}\text { Listening to own heart when } \\
\text { deciding }\end{array}$ & Never & Rarely & Often & Always \\
\hline Receiving donations & Never & Rarely & Often & In all occasions \\
\hline Accepting the situation & No & Yes & & \\
\hline $\begin{array}{l}\text { Remain in the state of } \\
\text { introspection }\end{array}$ & $\begin{array}{l}\text { Take care } \\
\text { about others' } \\
\text { opinions }\end{array}$ & $\begin{array}{l}\text { View yourself } \\
\text { through others' } \\
\text { eyes, }\end{array}$ & $\begin{array}{l}\text { Self-reference } \\
\text { point }\end{array}$ & \\
\hline Spending time in nature & Not at all & Sometimes & Often & A lot of time \\
\hline Defending own positions & Always & Sometimes & Never & \\
\hline Power of donating & $\begin{array}{l}\text { Doesn't } \\
\text { appreciate }\end{array}$ & $\begin{array}{l}\text { Appreciates } \\
\text { but doesn't } \\
\text { give donations }\end{array}$ & $\begin{array}{l}\text { Appreciates } \\
\text { and gives } \\
\text { donations }\end{array}$ & $\begin{array}{l}\text { Extremely } \\
\text { appreciates } \\
\text { and gives } \\
\text { donations }\end{array}$ \\
\hline $\begin{array}{l}\text { Accepting responsibility for the } \\
\text { situation }\end{array}$ & No & Partially & Yes & \\
\hline
\end{tabular}

Source: Authors' work

Figure 2

Deductive Case Based Rule Graph of newly created expert system

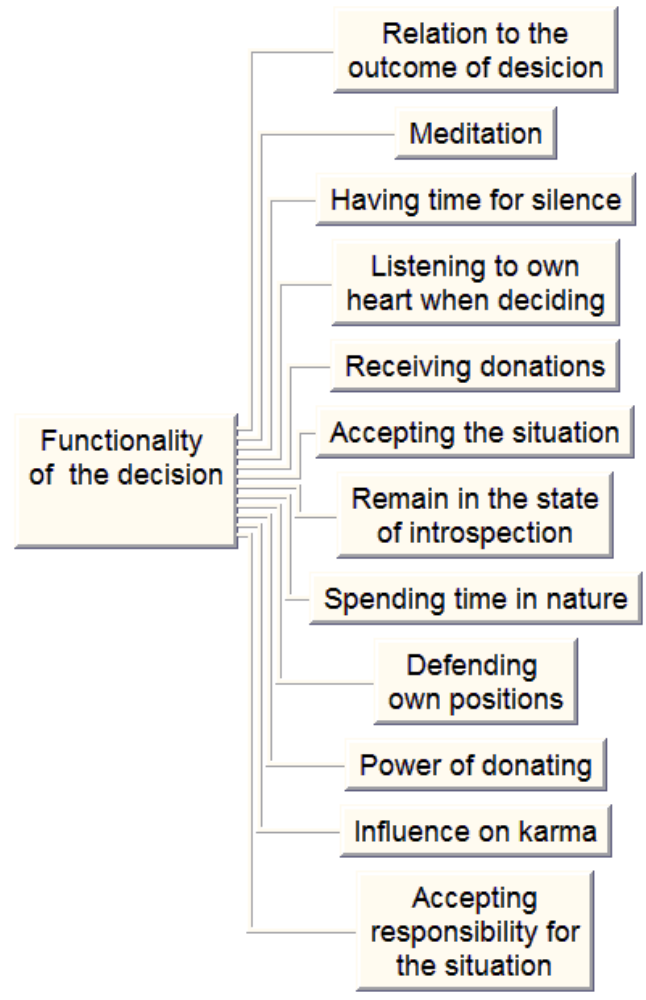

Source: Authors' work 
Table 4 presents IF-THEN rules (knowledge base ES) that were generated based on the degree of their importance for the success (functionality) of the decisions. When a manager wants to check whether some of his decisions resulted in new functional decisions which exceed expectations, meet expectations, or the problem will be partially solved or the decision will be fully non-functional, it is necessary to enter values of the most informative attributes in the Cases card, and by running the Reason command (deductive reasoning) an answer is obtained. Thus, it is not necessary to enter all 31 attributes but only the values of 13 the most informative attributes, which significantly simplify the process of decision making.

\section{Table 4}

Knowledge base (IF THEN rules) of newly created expert system

\begin{tabular}{|c|c|c|c|c|c|c|c|c|c|c|c|}
\hline Relation to the Meditation & Having time fo & Listening to o1 & Receiving don & Accepting the & Remain in the & Spending time & Defending ow & Power of dona & Influence on $\mathrm{k}$ & Accepting res & Functionality \\
\hline Related to the Not at all & Not at all & Never & * & * & * & * & $\star$ & * & * & $\star$ & Proble Meets \\
\hline Related to the Not at all & Not at all & Rarely & * & * & * & * & * & * & * & * & Partially solve \\
\hline Related to the Not at all & Sometimes & $*$ & Rarely, Often & * & * & * & * & * & * & * & Meets expecti \\
\hline Related to the Not at all & Sometimes & * & In all occasior & $\star$ & * & $\star$ & $\star$ & * & * & $\star *$ & Exceeds expe \\
\hline Related to the Not at all & A lot of time & * & * & * & * & * & $\star$ & * & * & * & Exceeds expe \\
\hline Related to the Often & * & * & * & * & * & * & * & * & * & * & Partially solve \\
\hline Related to the Sometimes & Not at all & * & * & * & * & * & * & * & * & * & Meets expect: \\
\hline Related to the Sometimes & Alot of time & * & * & * & $*$ & ${ }^{*}$ & * & ${ }^{*}$ & * & * & Meets expect: \\
\hline Related to the Sometimes & Sometimes & * & * & No & $*$ & * & * & $*$ & * & $\star$ & Exceeds expe \\
\hline Related to the Sometimes & Sometimes & $*$ & * & Yes & Take care abo & * & $\star$ & * & $*$ & * & Meets expect: \\
\hline Related to the Sometimes & Sometimes & * & * & Yes & Self-reference & * & * & * & * & * & Exceeds expe \\
\hline Related to the * & * & * & * & * & Take care abo & * & $\star$ & * & * & $\star$ & Meets expect; \\
\hline Related to the * & * & * & * & * & View yourself & Sometimes & * & * & * & * & Partially solve \\
\hline Related to the * & * & * & * & $\star$ & View yourself & Often & * & * & * & $\star$ & Meets expect; \\
\hline Related to the * & * & $*$ & * & * & Self-reference & * & $*$ & $*$ & * & $\star *$ & Meets Excee \\
\hline Accept "the w Not at all & * & Never & * & * & * & * & Always & * & * & * & Exceeds expe \\
\hline Accept "the w Often & * & Never & * & * & * & $\star$ & Always & * & * & * & Exceeds expe \\
\hline Accept "the w Sometimes & * & Never & * & $\star$ & * & * & Always & $*$ & * & $\star$ & Meets expect; \\
\hline Accept "the w * & ${ }^{*}$ & Often & * & * & $*$ & * & Always & Appreciates b & * & * & Partially solve \\
\hline Accept "the w * & * & Often & * & * & * & * & Always & Appreciates a & * & * & Exceeds expe \\
\hline Accept "the w * & $*$ & Rarely & * & * & * & * & Always & $*$ & * & $\star$ & Meets expect: \\
\hline Accept "the w Not at all & * & Always & * & * & * & * & Always & * & * & * & Meets expect; \\
\hline Accept "the w Often & * & Always & * & $\star$ & * & 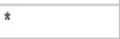 & Always & * & * & $\star$ & Exceeds expe \\
\hline Accept "the w * & * & * & * & * & * & $\star$ & Sometimes & $\star$ & * & $\star$ & Meets expect; \\
\hline Accept "the w * & * & * & * & * & * & * & Never & * & Trying to makı & $\star$ & Exceeds expe \\
\hline Accept "the w * & * & * & * & * & * & * & Never & * & Influences sig| & Partially & Meets expect: \\
\hline Accept "the w * & * & * & * & * & * & * & Never & * & Influences sig| & Yes & Meets Excee \\
\hline
\end{tabular}

Source: Authors' work

\section{Conclusions}

Certainly, this paper has demonstrated that spiritual intelligence implies an adaptive and problem-solving capacity. SQ is necessary to , find and use the deepest inner resources from which come the capacity to care and the power tolerate and adapt" (George, 2006; pp. 3).

Aiming to induce managers' awareness of the fact how spiritual intelligence components affect the decision making performances, research revealed that they should work on their own spiritual development. Precisely, their different answers prove the significance of spiritual intelligence for successful decision-making. However, managers typically rely on tacit and non-explicit knowledge. They generally do not notice the significance of these attributes and even when they do, they consider them as attributes of rational intelligence. But taking that preferred value of an attribute in relation to the outcome for these two types of intelligence is completely opposite (because of two different value systems), managers have entirely different views.

Therefore, proposed expert system should "discover" and "generate" new base of knowledge and convert it into explicit knowledge. This also includes definition of the factors that mostly contribute to the functionality of the decision, as the result of the inductive approach in an expert system building process. These components represent research agenda that should be addressed by further research but also main categories which provide the instructions for a new discourse on managerial decision making. 
However, this does not imply that organizations should have and promote strong spiritual culture. Namely, many studies (e.g. Benner et al., 2003; Boisnier et al., 2003) indicated that strong cultures can reduce flexibility of the organization in terms of its ability to change and innovate and that is pretty undesirable feature of the modern organization in the extremely unpredictable environment.

\section{References}

1. Benner, M.J., Tushman, M.L. (2003), "Exploitation, exploration, and process management: the productivity dilemma revisited", Academy of Management Review, Vol. 28, No. 2, pp. 238-56.

2. Bennet, A., Bennet, D. (2007), The knowledge and knowing of spiritual learning, VINE: The journal of information and knowledge management systems Vol. 37, No. 2, pp. 150-168.

3. Boisnier, A., Chatman, J.A. (2003), "The role of subcultures in organizations", in Peterson, R. and Mannix, E. (Ed.), Leading and Managing People in Dynamic Organizations, Earlbaum, pp. 87-112.

4. Butănescu, V. R. C. (2013), The Imperative of Addressing the Contemporary Crisis of Economics with Spiritual Intelligence. Procedia Economics and Finance, Vol. 6, pp. 19-24.

5. Chin, S. T. S., Raman, K., Yeow, J. A., Eze, U. C. (2012), Relationship Between Emotional Intelligence And Spiritual Intelligence In Nurturing Creativity And Innovation Among Successful Entrepreneurs: A Conceptual Framework. Procedia-Social and Behavioral Sciences, Vol. 57, pp. 261-267.

6. Clark, L., Leedy, S., McDonald, L., Muller, B., Lamb, C., Mendez, T., Kim, S. Schonwetter, R. (2007), "Spirituality and job satisfaction among hospice interdisciplinary team members", Journal of Palliative Medicine, Vol. 10, No. 6, pp. 1321-8.

7. Cole, B.S., Hopkins, C.M., Tisak, J., Steel, J.L., Carr, B.I. (2008), "Assessing spiritual growth and spiritual decline following a diagnosis of cancer: reliability and validity of the spiritual transformation scale", Psycho-oncology, Vol. 17, No. 2, pp. 112-21.

8. Fairholm, G.W. (1996), Spiritual leadership: fulfilling whole-self needs at Work, Leadership \& Organization Development Journal, Vol. 17, No. 5, pp.11-17.

9. Gardner, H. (2000), A case against spiritual intelligence. The international journal for the psychology of religion, Vol. 10, No. 1, pp. 27-34.

10. George, M. (2006), Practical application of spiritual intelligence in the workplace. Human Resource Management International Digest, Vol. 14, No. 5, pp. 3-5.

11. Greenfield, E.A., Vaillant, G.E., Marks, N.E. (2009), "Do formal religious participation and spiritual perceptions have independent linkages with diverse dimensions of psychological well-being?", Journal of Health and Social Behavior, Vol. 50, No. 2, pp. 196-212.

12. Ingersoll, R. E., Baver, A. L. (2004), „An integral approach to spiritual wellness in school counseling settings". Professional School Counseling, Vol. 7, pp. 301-308.

13. Joseph, R., Newburg, A., Albright, C. R., Rausch, C. A., Persinger, M., James, W., Nietzsche, F. (2003), Neurotheology, University Press.

14. Kadkhoda, M. Jahani,H. (2012), „Problem-solving capacities of spiritual intelligence for artificial intelligence", Procedia - Social and Behavioral Sciences Vol. 32, pp. $170-175$.

15. Lerner, M. (2000), Spirit Matters, Hampton Roads.

16. Luckock, T. (2008), "Spiritual Intelligence in Leadership Development", Educational Management Administration \& Leadership, Vol. 36, No. 3, pp. 373-391.

17. Marques, J. F. (2006), "The spiritual worker: An examination of the ripple effect that enhances quality of life in-and outside the work environment", Journal of Management Development, Vol. 25, No. 9, pp. 884-895.

18. Newburg, A., D'Aquili, E., Rause, V. (2002), Why God won't go away: Brain science and the biology of belief, Ballentine Books.

19. Klenke, K. (2003), "The "S" factor in leadership education, practice, and research", Journal of Education for Business, Vol. 79, No. 1, pp. 56-60.

20. Perrone, K.M., Webb, L.K., Wright, S.L., Jackson, Z.V., Ksiazak, T.M. (2006), "Relationship of spirituality to work and family roles and life satisfaction among gifted adults", Journal of Mental Health Counselling, Vol. 28, No. 3, pp.253-68. 
21. Rezaei, H. (2012), "The application of information technology and its relationship with organizational intelligence". Procedia Technology, Vol. 1, pp. 94-97.

22. Sisk, D. (2002), ,Spiritual intelligence: the tenth intelligence that integrates all other intelligences", Gifted Education International, Vol. 16, pp. 208-212.

23. Tombaugh, J.R., Mayfield, C., Durand, R. (2011), "Spiritual expression at work: exploring the active voice of workplace spirituality", International Journal of Organizational Analysis Vol. 19, No. 2, pp. 146-170.

24. Vaughn, F. (2002), "What is Spiritual Intelligence?", Journal of Humanistic Psychology, Vol. 42, No. 2, pp. 16-33.

25. White, S.R. (2006), „Spirituality and the Intellectual Development of College Students: The New Leadership Challenge in Higher Education", International Electronic Journal for Leadership in Learning, Vol.10., available at: http://iejll.synergiesprairies.ca/iejll/index.php/ijl/article/view/613 / (10 September, 2013)

26. Wolman, R. N. (2001), Thinking with your soul: Spiritual intelligence and why it matters, Harmony Books.

27. Zohar, D. (2005), „Spiritually Intelligent Leadership“, Leader to Leader, Vol. 38, pp. 45-1.

28. Zohar, D., Marshall, I. (2000), SQ: Spiritual Intelligence, The Ultimate Intelligence, Bloomsbury.

29. Zohar, D. Marshall, I. (2004), Spiritual Capital: Using our Rational, Emotional and Spiritual Intelligence to Transform Ourselves and Corporate Culture, Bloomsbury.

\section{About the authors}

Savo Stupar, PhD, is Assistant Professor at School of Economics and Business in Sarajevo, Department of Management and Information technology. He teaches courses in Business Informatics and Database Management Systems. His primary research interests lie in the Expert systems, Decision support systems, Artificial intelligence. He is an author of numerous research papers, including several chapters and books. Author can be contacted at savo.stupar@efsa.unsa.ba

Amila Pilav-Velić, Msc, is a senior teaching assistant at School of Economics and Business in Sarajevo, Department of Management and Information technology. Currently, she is a PhD student at School of Economics and Business in Sarajevo, within international Tempus project created in collaboration with the University of Vienna and the University of Ljubljana. Her primary research interests lie in the Innovation management, Business Process Management (Innovations) and Inter-organizational collaboration. She is an author of numerous research papers, including one chapter and book. For the last six months she has been promoted in the Head of faculty development centre. Author can be contacted at amila.pilavvelic@efsa.unsa.ba

Elvir Šahić, Msc, is a senior teaching assistant at School of Economics and Business in Sarajevo, Department of Management and Organization. His research interests lie in Sociology, Sociocultural anthropology, but also political philosophy. Therefore, majority of his research publications reflect these interests. Author can be contacted at elvir.sahic@efsa.unsa.ba 